\title{
Comparative investigations of influence of chemical admixtures on pozzolanic and hydraulic activities of fly ash with the use of thermal analysis and infrared spectroscopy
}

\author{
Barbara Pacewska • Iwona Wilińska
}

Received: 13 September 2014/ Accepted: 28 November 2014/Published online: 24 December 2014

(C) The Author(s) 2014. This article is published with open access at Springerlink.com

\begin{abstract}
The aim of this work is to investigate the influence of selected alkaline activators on pozzolanic and hydraulic activities of fly ashes using thermal analysis (TG/ DTG) and infrared spectroscopy (FTIR). Two types of fly ashes differing in chemical compositions, especially content of calcium components, were selected for investigations. The study was carried out for two types of samples: (1) fly ash-lime paste performed with low-calcium fly ash and (2) a paste performed with high-calcium fly ash and water without introduction of additional amount of $\mathrm{Ca}(\mathrm{OH})_{2}$. Chemical admixtures $\mathrm{NaOH}, \mathrm{Na}_{2} \mathrm{SO}_{4}$, and $\mathrm{Na}_{2} \mathrm{CO}_{3}$ were added to both the types of samples. It was confirmed that influence of chemical activators on pozzolanic and hydraulic properties of fly ashes strictly depends on the kind of fly ash and availability of $\mathrm{Ca}(\mathrm{OH})_{2}$. For example, in case of highcalcium fly ash, the most active action was exhibited by $\mathrm{NaOH}$ solution.
\end{abstract}

Keywords Fly ash · Pozzolanic activity - Hydraulic activity $\cdot$ Activation

\section{Introduction}

In recent years, more and more attention is paid to the necessity to reduce emission of $\mathrm{CO}_{2}$ to atmosphere. Therefore, development of new binders which may be an alternative for traditional Portland cement becomes priority objective, and it is an ongoing research topic in the

B. Pacewska $(\bowtie) \cdot$ I. Wilińska

Faculty of Civil Engineering, Mechanics and Petrochemistry, Institute of Chemistry, Warsaw University of Technology, Lukasiewicza 17 St., 09-400 Plock, Poland

e-mail: bpacewska@pw.plock.pl scientific community. In these new binding materials, the greatest possible quantity of Portland cement clinker is substituted by other aluminosilicate materials, such as slag, metakaolin, and fly ash [1-4], which are often chemically activated [5-9]. Cementless binders, such as geopolymers, are also intensively studied. In case of this type of binders, aluminosilicate materials undergo reactions in the presence of highly alkaline solutions and also often elevated temperature [10-12].

Fly ashes are frequently used as cement replacements or components of geopolymers. These waste materials exhibit the so-called pozzolanic activity. It means that they can react in the presence of water and available $\mathrm{Ca}(\mathrm{OH})_{2}$ at room temperature $[13,14]$. Products similar to these that are formed during cement hydration arise during pozzolanic reaction: hydrated calcium silicates of low degree of crystallinity and variable chemical composition (C-S-H phase), hydrated aluminate phases, and, in the presence of $\mathrm{SO}_{4}{ }^{2-}$, also sulfoaluminates such as ettringite and monosulfate. In case of mixtures of fly ash and cement, $\mathrm{Ca}(\mathrm{OH})_{2}$, which is necessary for the pozzolanic reaction, arises during cement hydration as one of its products. However, some kinds of fly ashes contain properly high amount of calcium compounds to exhibit self-cementing properties. It means that they are able to hardening in the presence of water but without introduction of additional amount of $\mathrm{Ca}(\mathrm{OH})_{2}$. The knowledge of kinetics of pozzolanic and hydraulic reactions, products which form in the presence of $\mathrm{Ca}(\mathrm{OH})_{2}$, their chemical composition, morphology, and structure is determinant for the use of the aluminosilicate materials also fly ashes.

Using fly ashes as high-volume cement replacements, deterioration of concrete properties such as setting time and early compressive strength is a problem. To counteract this, different kinds of chemical activators such as sodium and 
potassium hydroxides, $\mathrm{Na}_{2} \mathrm{SO}_{4}$, water glass, and others are used $[5,8,9,15]$. The research works undertaken in this field largely relate to the properties of the obtained final composites. Studies designed to explore the mechanisms of reactions of fly ashes in the presence of various activators are also important. Such investigations on the one hand extend the knowledge of mechanisms of physical and chemical processes, while on the other hand they allow the assessment of possibility of using selected activators in terms of durability of composites obtained. Knowledge of these long-term processes is essential especially due to the fact that the alkaline activation of industrial by-products, fly ash among them, is considered as an alternative to traditional Portland cement.

It is essential that not only the type of activator influences physical and chemical processes but also the kind of aluminosilicate materials used, also in the case when fly ashes are considered. The properties of fly ashes depend on the type of combusted solid fuel, technology of combustion, and desulfurization of gases. This leads to the fact that fly ashes of different origins may be also dissimilar in their chemical, phase and granulometric compositions, as well as grains morphology. For this reason, each type of fly ash requires individual studies for selecting the best activator and conditions of hardening.

In our previous work, we investigated pozzolanic and hydraulic activities of different fly ashes exhibiting various properties [16], their influence on cement hydration in case when they are used in typical amount, i.e., till 30 mass $\%$ [17], as well as the mechanism of early hydration of cement paste containing 30 mass $\%$ of conventional, lowcalcium, fly ash, and chemical activators such as $\mathrm{CaCl}_{2}$, $\mathrm{NaOH}$, and $\mathrm{Na}_{2} \mathrm{SO}_{4}$ [18]. In work [19], the influence of type of Portland cement as well as the amount of fly ash (40 and 80 mass\%) was shown. An attempt of chemical activation of pastes containing high amount of fly ash was also made. Interesting results were obtained when part of fly ash in a very high-volume fly ash binder was replaced by more active pozzolanic material which is spent catalyst from fluidized catalytic cracking installation [20].

The aim of this work is to investigate the influence of selected alkaline activators on pozzolanic and hydraulic activities of fly ashes using thermal analysis (TG/DTG) and infrared spectroscopy (FTIR). For this purpose, two types of fly ashes differing in chemical compositions, being the result of different types of coal combusted, were selected for investigations. One of the differences in chemical compositions of these fly ashes was the content of calcium components. Thus, it was evident at the beginning of the investigations that one of these fly ashes may exhibit some self-cementing properties (hydraulic activity) resulting from higher calcium content, while the second one needs introduction of $\mathrm{Ca}(\mathrm{OH})_{2}$ for hardening.

\section{Materials and methods}

Fly ashes

Two types of fly ash from power industry were used for these investigations: fly ash from conventional combustion of hard coal (the ash will be named in the further part of this work as PK) and from combustion of brown coal (named PB). Average chemical compositions of these fly ashes (recalculated into oxides) are presented in Fig. 1, while X-ray patterns are shown in Fig. 2. Figures 3a, 4a, and 8a present TG and DTG curves as well as IR spectra in comparison to results obtained for hydrated fly ashes. As it can be seen, PK ash has a low content of calcium compounds, and its phase composition is simpler compared to the PB. Quartz is the main component of both the ashes. In the case of $\mathrm{PB}$, calcium compounds occur in different forms: free $\mathrm{CaO}(<1 \%)$, anhydrite, anorthite, gehlenite, and calcite, which have different reaction abilities in the presence of water. For example, gehlenite is considered to be a phase of low hydraulic capability.

It was confirmed in the previous studies $[19,20]$ that PK exhibits pozzolanic activity. In the case of $\mathrm{PB}$ which contains higher amount of calcium compounds, it was assumed that this fly ash will exhibit some self-cementing properties in contact with water, despite the presence of certain phases of low reactivity. Therefore, study on the

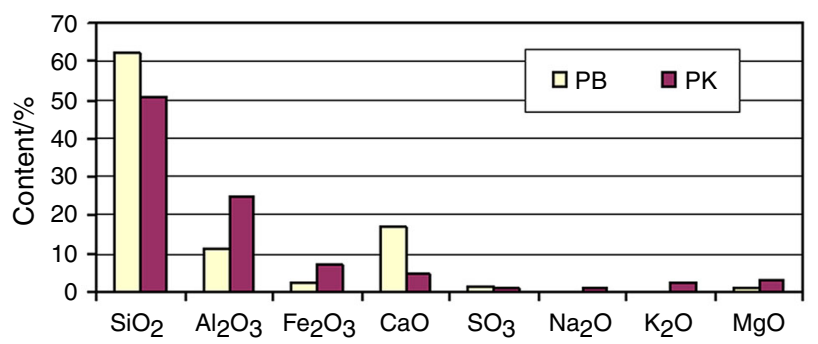

Fig. 1 Average chemical compositions of PB and PK fly ashes

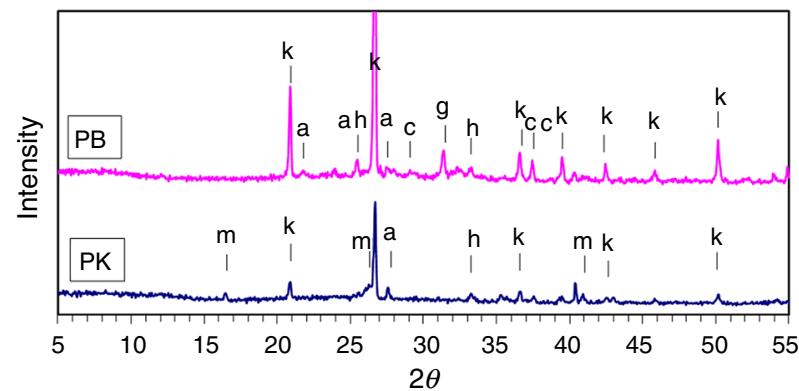

Fig. 2 X-ray patterns of PB and PK fly ashes. $k$ quartz, $m$ mullite, $a$ anorthite, $a$ anhydrite, $c$ calcite, $g$ gehlenite, $c c$ free $\mathrm{CaO}$, $h$ hematite 
Fig. 3 TG curves for fly ash pastes containing different chemical admixtures: a reference (without chemical admixtures), b $\mathrm{NaOH}$, c $\mathrm{Na}_{2} \mathrm{CO}_{3}, \mathbf{d ~ N a} \mathrm{SO}_{4} ; 1$ results for $\mathrm{PK}+\mathrm{Ca}(\mathrm{OH})_{2}$ pastes, 2 results for $\mathrm{PB}$ paste; $\mathrm{PB}-0 \mathrm{~d}$ and PK-0 d-TG curves for raw PB and $\mathrm{PK}$ ashes
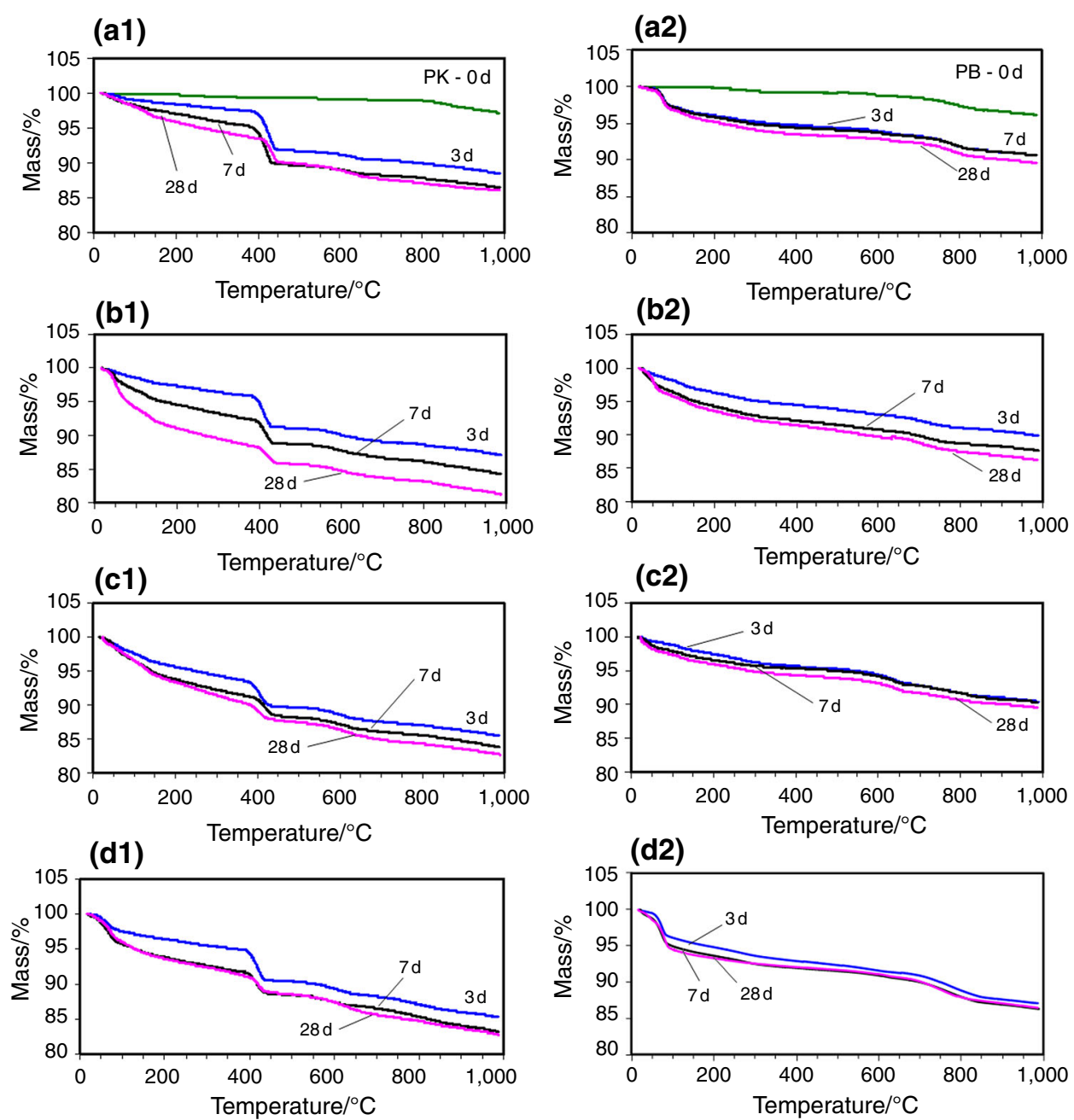

impact of chemical activators on reactivity of fly ashes was carried out for two types of pastes:

1. Fly ash-lime paste performed with PK to assess influence of chemical activators on pozzolanic activity of fly ash

2. A paste performed with $\mathrm{PB}$ and water without introduction of additional amount of $\mathrm{Ca}(\mathrm{OH})_{2}$ to assess influence of chemical activators on the ability to selfhardening of fly ash in the presence of water.

Samples and methods of investigations

Distilled water was added to dry components, i.e., $\mathrm{PK}+\mathrm{Ca}(\mathrm{OH})_{2}\left(70 \%\right.$ of $\mathrm{PK}$ and $30 \%$ of $\mathrm{Ca}(\mathrm{OH})_{2}$ by mass similarly as in [16]) as well as $\mathrm{PB}$, in such an amount that thorough mixing of ash paste was possible. The ratio of water/ solid was 0.5 for $\mathrm{PK}+\mathrm{Ca}(\mathrm{OH})_{2}$ and 0.7 for PB. Chemical admixtures $\left(\mathrm{NaOH}, \mathrm{Na}_{2} \mathrm{CO}_{3}\right.$, and $\left.\mathrm{Na}_{2} \mathrm{SO}_{4}\right)$ were introduced in amount to $3 \%$ of solid mass after their prior dissolving in the mixing water. Pastes obtained in such way were poured into small, sealed polyethylene bags. After 3, 7, and 28 days, samples were removed from bags and their hydration was stopped with the use of acetone. Then the samples were studied by thermal analysis and infrared spectroscopy.

Thermal analysis (TG, DTG) measurements were performed in nitrogen atmosphere using SDT 2960 Thermoanalyser produced by TA Instruments. Studies were carried out at the temperature range of $20-1,000{ }^{\circ} \mathrm{C}$, heating rate of $10{ }^{\circ} \mathrm{C}$ $\min ^{-1}$, sample mass of $9-13 \mathrm{mg}$, using an alumina crucible.

Infrared spectra were collected using FTIR spectrophotometer Genesis II, produced by Mattson. Samples were prepared as $\mathrm{KBr}$ pellets. Measurements were conducted for $4,000-400 \mathrm{~cm}^{-1}$ wavenumbers.

\section{Results and discussion}

The results of thermal analysis (TG and DTG curves) are presented in Figs. 3 and 4, respectively, while in Figs. 5-7, mass losses taking place at selected temperature ranges were given. Some limitations for the interpretation of thermal analysis results, especially mass losses, in the 
Fig. 4 DTG curves for fly ash pastes containing different chemical admixtures:

a reference (without chemical admixtures), b $\mathrm{NaOH}$, c $\mathrm{Na}_{2} \mathrm{CO}_{3}, \mathbf{d ~ N a} \mathrm{SO}_{4} ; \mathbf{1}$ results for $\mathrm{PK}+\mathrm{Ca}(\mathrm{OH})_{2}$ pastes, 2 results for PB pastes; PB-0 d and PK-0 d-DTG curves for raw $\mathrm{PB}$ and $\mathrm{PK}$ ashes
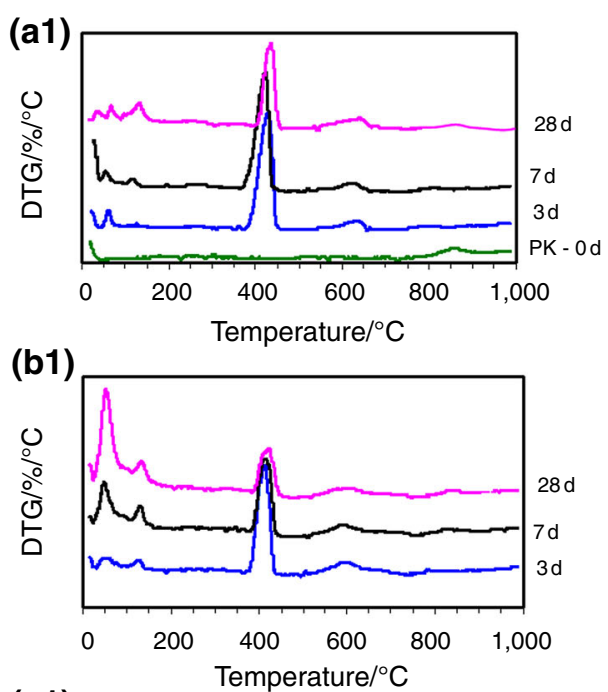

(c1)
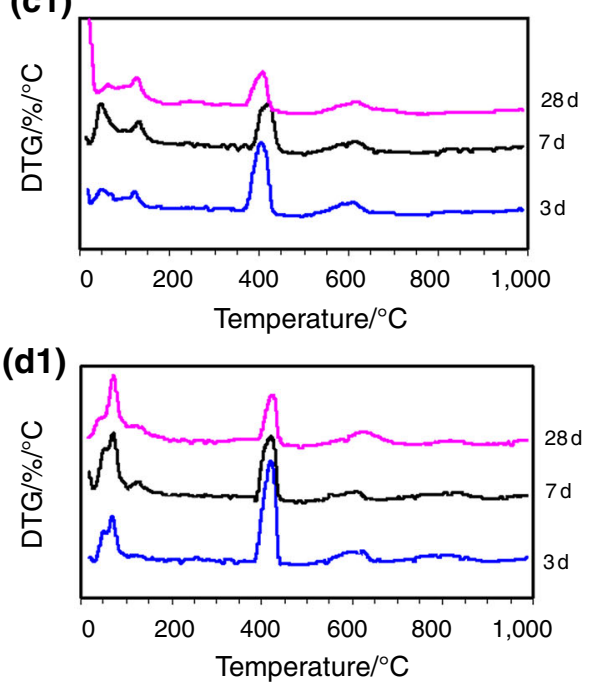

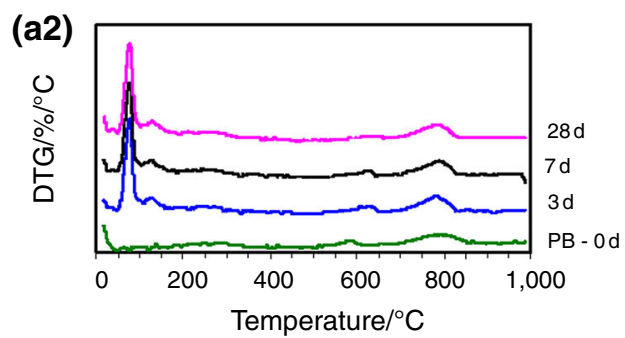

(b2)
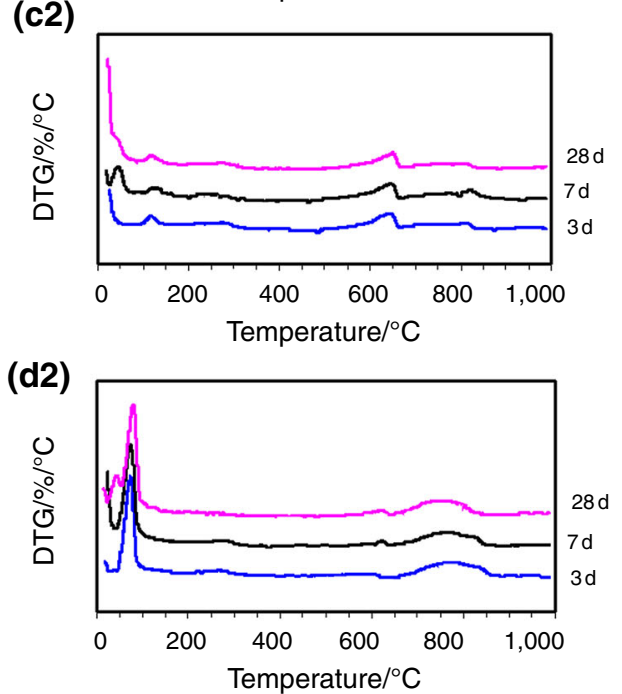
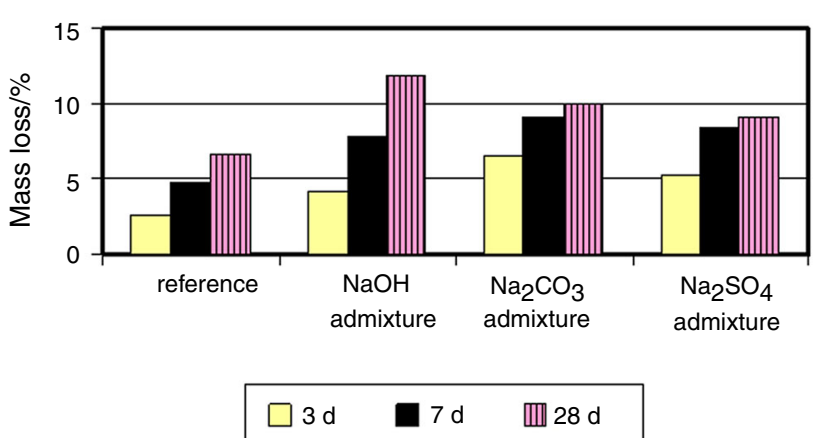

Fig. 5 Mass loss up to about $380{ }^{\circ} \mathrm{C}$ for PK pastes (evaporation of water bound in hydrates)

context of reactivity of cementitious systems were described earlier elsewhere [20]. For example, hydrated products may contain different amounts of water; consequently, the amount of water bound in hydrates may not reflect the degree of hydration. Thus, quantitative interpretation

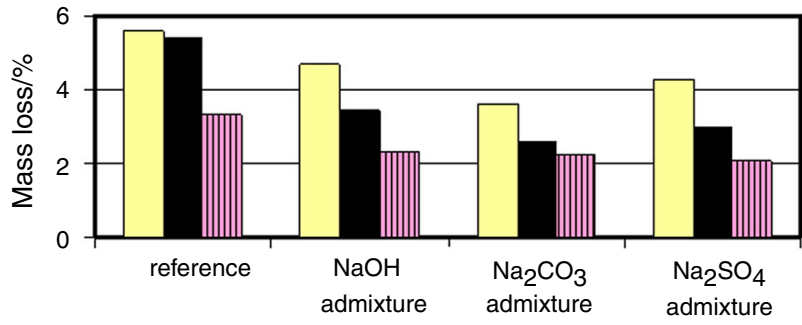

$$
\square 3 d \quad \square 7 d \quad \text { 血 } 28 d
$$

Fig. 6 Mass loss at about $380-450{ }^{\circ} \mathrm{C}$ for $\mathrm{PK}$ pastes (evaporation of water bound in $\left.\mathrm{Ca}(\mathrm{OH})_{2}\right)$

included in this work and based on mass losses is only an estimation. IR spectra for investigated samples after different periods of hydration are presented in Fig. 8. Additionally, the results registered for dry fly ashes PK and PB are also included in Figs. 3, 4, and 8 for comparison. 


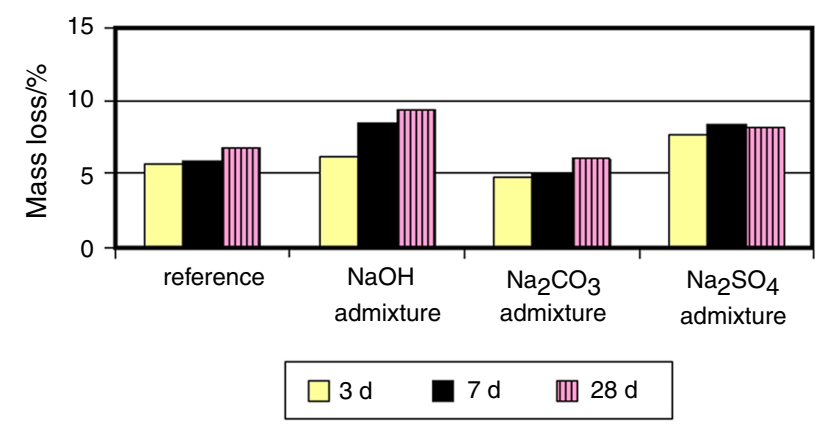

Fig. 7 Mass loss up to about $500{ }^{\circ} \mathrm{C}$ for $\mathrm{PB}$ pastes (evaporation of water bound in hydrates)

\section{Hydration without chemical admixtures}

It is believed that hydration of fly ash first starts from its dissolution and moving ions of $\mathrm{Na}^{+}$and $\mathrm{K}^{+}$to solution, then aluminate and silicate ions. In the liquid phase, the silicate and aluminate ions react with $\mathrm{Ca}^{2+}$ and create $\mathrm{C}-$ $\mathrm{S}-\mathrm{H}$ and calcium aluminate phases (mainly $\left.\mathrm{C}_{4} \mathrm{AH}_{13}\right)^{1}$. In case of the solution rich in $\mathrm{Na}^{+}$ions, they incorporate into forming hydrated products. The solubility of silica increases with the increasing $\mathrm{pH}$. In the presence of gypsum, ettringite is formed [13].

TG and DTG curves registered for hydrated pastes are different from those for dry fly ashes, as it can be seen in Figs. 3a1, a2, and 4a1, a2. For pastes containing PK fly ash and additionally introduced $\mathrm{Ca}(\mathrm{OH})_{2}$, the course of $\mathrm{TG}$ (Fig. 3a1) and DTG (Fig. 4a1) curves is similar to that for hydrated Portland cement. For such samples, three main mass losses may be distinguished on TG curves: the first occurs at temperature to about $380{ }^{\circ} \mathrm{C}$, and it is connected with evaporation of water bound in various products of hydration, such as $\mathrm{C}-\mathrm{S}-\mathrm{H}$ phase, hydrated calcium aluminates, and sulfoaluminates; the second at about $380-450{ }^{\circ} \mathrm{C}$ is an effect of decomposition of $\mathrm{Ca}(\mathrm{OH})_{2}$, while the third at temperatures above $500{ }^{\circ} \mathrm{C}$ is predominatingly related to decomposition of carbonates.

TG and DTG curves (Figs. 3a1, 4a1) as well as adequate mass losses (Figs. 5, 6) confirm low reactivity of PK fly ash in the presence of $\mathrm{Ca}(\mathrm{OH})_{2}$ in case when the reaction proceeds without activators. It is confirmed by low amount of water bound in hydrates and the greatest amount of $\mathrm{Ca}(\mathrm{OH})_{2}$ which was not consumed in the pozzolanic reaction, in comparison with the other samples. Gradual development of pozzolanic activity of PK fly ash is visible, i.e., an increase of the amount of bound water in hydrates with time and clear decrease of $\mathrm{Ca}(\mathrm{OH})_{2}$ in the period between 7 and 28 days of hydration. The shapes of DTG

\footnotetext{
${ }_{1}$ Abbreviations used in cement chemistry: $\mathrm{C}-\mathrm{CaO}, \mathrm{A}-\mathrm{Al}_{2} \mathrm{O}_{3}, \mathrm{~S}-$ $\mathrm{SiO}_{2}, \mathrm{H}-\mathrm{H}_{2} \mathrm{O}, \mathrm{N}-\mathrm{Na}_{2} \mathrm{O}$.
}

curves indicate that hydrates type of $\mathrm{C}-\mathrm{S}-\mathrm{H}$ are formed firstly, and phases of hydrated aluminates appear in the later periods.

Similar conclusions can be drawn by analyzing the IR spectra recorded for $\mathrm{PK}$ ash and its paste with $\mathrm{Ca}(\mathrm{OH})_{2}$ (Fig. 8a1). On the 3rd day of hydration, the IR spectrum resembles mixture of non-hydrated $\mathrm{PK}$ fly ash and $\mathrm{Ca}(\mathrm{OH})_{2}$ : there is a clearly visible band at about $3,640 \mathrm{~cm}^{-1}$ corresponding to the vibration of $\mathrm{OH}^{-}$in $\mathrm{Ca}(\mathrm{OH})_{2}$ [14] as well as bands at 1,420 and $875 \mathrm{~cm}^{-1}$ related to vibration of $\mathrm{CO}_{3}^{2-}$ in $\mathrm{CaCO}_{3}$ which was introduced into the paste with $\mathrm{Ca}(\mathrm{OH})_{2}$. The main, intense, broad ash band with the extreme at $1,070 \mathrm{~cm}^{-1}$, typical for vibrations of $\mathrm{Si}(\mathrm{Al})-\mathrm{O}$ in ashes [20, 21], is also visible. Very weak bands, almost invisible after 3 days of hydration, at about 3,500 and $1,660 \mathrm{~cm}^{-1}$ correspond to vibrations of water molecules. Minimal intensities of these bands confirm that pozzolanic reaction occurred only slightly after 3 days. When the hydration time is extended, intensity of the band at $3,660 \mathrm{~cm}^{-1}$, characteristic for $\mathrm{Ca}(\mathrm{OH})_{2}$, decreases. At the same time, the band of valence vibrations of water molecules at $3,100-3,600 \mathrm{~cm}^{-1}$ deepens, and a clear band of medium intensity at about $1,640 \mathrm{~cm}^{-1}$, related to deformational vibrations of $\mathrm{H}-\mathrm{O}-\mathrm{H}$, appears. The progress of pozzolanic reaction is evidenced not only by the reduction of intensity of the band characteristic for $\mathrm{Ca}(\mathrm{OH})_{2}$ but also by shifting the maximum of the main ash band toward lower wavenumbers. Moreover, in 28th day of hydration, the band at $975 \mathrm{~cm}^{-1}$, characteristic for new formed $\mathrm{C}-\mathrm{S}-\mathrm{H}$ phase, is visible. Comparing the results obtained in this work with those presented in [16], it can be concluded that PK fly ash shows better pozzolanic activity during 28 days of hydration than the previously investigated fly ash also coming from conventional combustion of hard coal.

Hydration of high-calcium fly ash $\mathrm{PB}$, for which additional amount of $\mathrm{Ca}(\mathrm{OH})_{2}$ was not introduced, proceeds in a distinctly different way. The presence of $\mathrm{Ca}(\mathrm{OH})_{2}$ in this type of sample is not recorded on TG/DTG during all period of the investigations (Figs. 3a2, 4a2). It confirms that only very small amount of calcium is present in this fly ash as free $\mathrm{CaO}$, hydration of which might result in formation of $\mathrm{Ca}(\mathrm{OH})_{2}$. Small amounts of hydrated phase of $\mathrm{C}-\mathrm{S}-\mathrm{H}$ as well as hydrated aluminates and sulfoaluminates, possible to create in such conditions, are formed relatively quickly, already in the first 3 days. Anhydrite, present in $\mathrm{PB}$, undergoes reaction and sulfoaluminates appear. Probably it may be main reaction occurring in early periods of hydration. The amount of bound water for PB fly ash during first days of its hydration is similar to results for $\mathrm{PK}+\mathrm{Ca}(\mathrm{OH})_{2}$ mixture after 7 days. It may suggest that PB earlier develops its activity compared to PK. In the following days, progress of hydration of ash $\mathrm{PB}$ is rather 
Fig. 8 IR spectra for fly ash pastes containing different chemical admixtures:

a reference (without chemical admixtures), b $\mathrm{NaOH}$, c $\mathrm{Na}_{2} \mathrm{CO}_{3}, \mathbf{d ~ N a} \mathrm{SO}_{4} ; \mathbf{1}$ results for $\mathrm{PK}+\mathrm{Ca}(\mathrm{OH})_{2}$ pastes, 2 results for PB pastes; PB-0 d and PK-0 d-IR spectra for raw $\mathrm{PB}$ and $\mathrm{PK}$ ashes
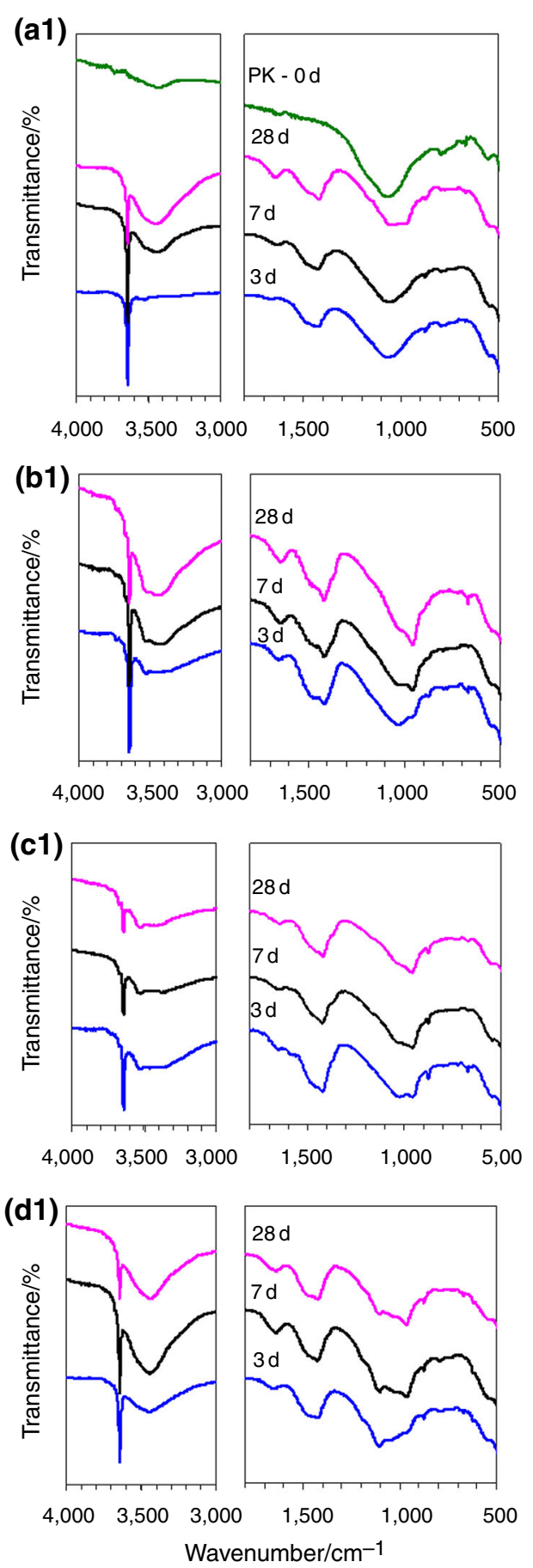

(a2)
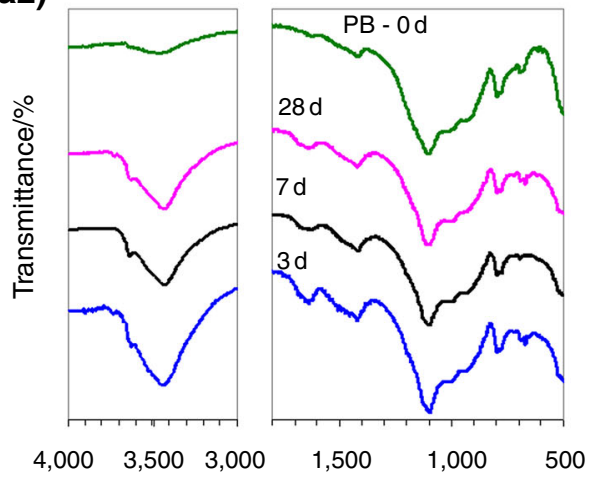

(b2)
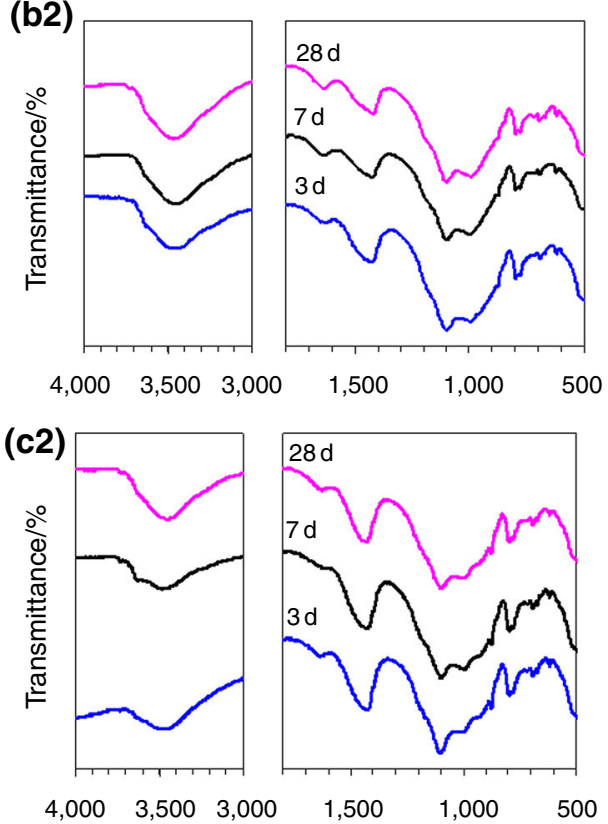

(d2)

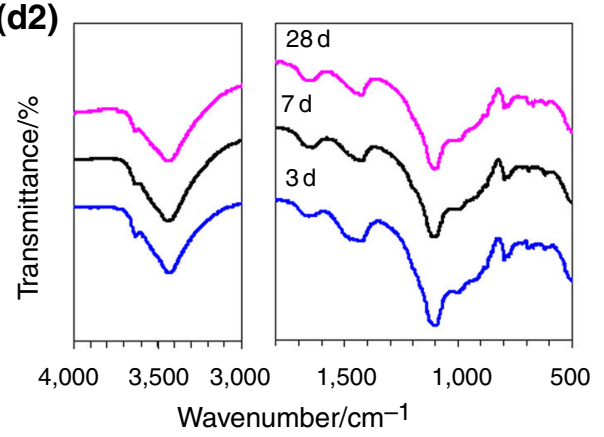

small, as evidenced by TG/DTG (Figs. 3a2, 4a2) curves and mass losses (Fig. 7). Analysis of the IR spectra of hydrated ash PB without activating admixtures also confirms the above findings (Fig. 8a2). The most pronounced changes in shape of IR spectrum of hydrated ash PB, compared to the result for raw fly ash, are due to the appearance of the bands of valence and deformation vibrations of water molecules, with the extreme, respectively, at 3,440 and $1,640 \mathrm{~cm}^{-1}$, and the band at
$3,640 \mathrm{~cm}^{-1}$ indicating the presence of free $\mathrm{OH}$ groups. Distinct differences in the IR spectra in the wavenumbers range $750-1,200 \mathrm{~cm}^{-1}$ are not observed. However, gradual disappearing of the band at about $930 \mathrm{~cm}^{-1}$ probably corresponding to $\mathrm{Al}-\mathrm{O}$ vibrations can be observed with time progress. It suggests some transformations in aluminosilicate phases of fly ash. Moreover, band at about $1,000 \mathrm{~cm}^{-1}$ is visible, indicating the formation of new aluminosilicate products. Some changes in the shape of 
spectrum at $580-700 \mathrm{~cm}^{-1}$ are also visible. For raw fly ash in this range of wavenumbers, the bands at 678,612 , and $595 \mathrm{~cm}^{-1}$ characteristic for anhydrite [21] are observed (the main band for $\mathrm{SO}_{4}^{2-}$ vibration in anhydrite is not visible because it overlaps with the strong band for ash at $1,100 \mathrm{~cm}^{-1}$ ). Thus, the obtained results confirm that PB fly ash exhibits weak binding properties. However, PB fly ash shows its activity earlier compared with PK.

Introduction of admixtures of chemical activators should result in an increase of reactivity of the studied systems and faster formation of compounds of binding properties. In the case of PK fly ash, it may be expected to improve the solubility of grains of fly ash and results in faster binding of $\mathrm{Ca}(\mathrm{OH})_{2}$ during pozzolanic reaction, whereas in the case of ash PB situation, it is more complicated because of its complex composition and lower availability of $\mathrm{Ca}^{2+}$ ions coming only from ash grains. The increase in the solubility of the PB grains under the influence of activators would also be beneficial and accelerate further reaction of grain ash. However, the problem of releasing $\mathrm{Ca}^{2+}$ from weakly reactive phases seems to be equally important.

\section{Action of $\mathrm{NaOH}$ admixture}

One of activators used in this work is $\mathrm{NaOH}$ being a strong base and a compound that dissolves very easily in water. Introduction of solution of $\mathrm{NaOH}$ into fly ashes causes increase in $\mathrm{OH}^{-}$concentration in the system in comparison with the situation when only water is used. Thus, it may be expected that in such conditions, the grains of fly ash will undergo dissolution easier. Silicate and aluminate ions move into solution where they may undergo further reactions. Such activating action of $\mathrm{NaOH}$ is clearly confirmed by results obtained by thermal analysis (Figs. 3b, 4b, 5, 6). In the case of PK, distinct increase of water bound in hydrates and reduction of $\mathrm{Ca}(\mathrm{OH})_{2}$ amount are visible. It can also be seen that the activating effect evolves with time of hydration. Comparing with the results for PK activated with other admixtures, one may conclude that the action of $\mathrm{NaOH}$ is slightly weaker in the initial stages of hydration (till 7th day) which is evidenced by lower amount of water bound in hydrates as well as greater content of $\mathrm{Ca}(\mathrm{OH})_{2}$. It is possible that in high alkali solution of $\mathrm{NaOH}$, some limitation of dissolution of solid $\mathrm{Ca}(\mathrm{OH})_{2}$ may take place. It also may be expected that as a result of increase of concentration of $\mathrm{OH}^{-}$ions on account of coexistence of $\mathrm{NaOH}$ and $\mathrm{Ca}(\mathrm{OH})_{2}$, some products similar to aluminosilicate gel that form in case of geopolymer binders are created beside $\mathrm{C}-\mathrm{S}-\mathrm{H}$ phase and phases of hydrated aluminates.

The IR spectra of pastes of $\mathrm{PK}+\mathrm{Ca}(\mathrm{OH})_{2}$ activated with $\mathrm{NaOH}$ show gradual formation of new phases of hydrates (Fig. 8b1). As early as on the 3rd day of hydration, the main band for fly ash is displaced toward lower wavenumbers (to around $1,030 \mathrm{~cm}^{-1}$ ). At the same time, a band at about $960 \mathrm{~cm}^{-1}$ appears, showing the formation of $\mathrm{C}-\mathrm{S}-\mathrm{H}$ type products. This band increases its intensity with time of hydration with simultaneous disappearance of the main band of ash. The position of the discussed band is slightly different from location of the band characteristic for conventional $\mathrm{C}-\mathrm{S}-\mathrm{H}$ phase derived from hydration of cement $\left(970 \mathrm{~cm}^{-1}[14,5]\right)$, which shows some differences in the products formed. Such position of the band, it is about $960 \mathrm{~cm}^{-1}$, for activated samples may be related to $\mathrm{Si}-\mathrm{O}-\mathrm{Si}$ vibrations characteristic for $\mathrm{C}-\mathrm{S}-\mathrm{H} /$ $\mathrm{C}-\mathrm{A}-\mathrm{S}-\mathrm{H}$ gel [5]. Moreover, changes in the shape of bands characteristic for carbonates $\left(1,350-1,550 \mathrm{~cm}^{-1}\right)$ compared to the results obtained for a reference sample indicate transformations occurring in carbonate phases.

Activating action of the solution of $\mathrm{NaOH}$ is also observed in the case of PB fly ash. In the presence of $\mathrm{NaOH}$, greater quantity of water is bound in the hydrated forms of the reaction products, which is especially observed till 7th day of hydration (Fig. 7). Progress of reaction between 7th and 28th day of hydration is negligible. Products arising in the presence of $\mathrm{NaOH}$ are different from those which are formed in the environment of water only. It is evidenced by TG and DTG (Figs. 3b2, $4 \mathrm{~b} 2)$. When hydration takes place in water, the formed hydrated compounds undergo dehydration mainly at temperatures till $150{ }^{\circ} \mathrm{C}$, whereas products formed in highly alkaline $\mathrm{NaOH}$ solution dehydrate at distinctly broader range of temperature. Very small effect appears on DTG curves at about $250{ }^{\circ} \mathrm{C}$ for $\mathrm{PB}$ activated with $\mathrm{NaOH}$ as well as with the other alkaline activators (this effect is slightly more visible for $\mathrm{Na}_{2} \mathrm{SO}_{4}$ admixture). Probably, it is peak characteristic for gehlenite hydrate $\left(\mathrm{C}_{2} \mathrm{ASH}_{8}\right)$, which may be a product of hydration of gehlenite, one of the components of the fly ash. $\mathrm{C}_{2} \mathrm{ASH}_{8}$ may also be formed in reaction between the amorphous $\mathrm{SiO}_{2}$ and calcium aluminate hydrate [22], more likely occurring in the presence of alkaline activators. This finding needs to be confirmed by other studies. Some of above conclusions are confirmed by IR spectra (Fig. 8b2). It can be seen that as early as on the 3rd day of hydration an intense, clear band appears at $994 \mathrm{~cm}^{-1}$, indicating the formation of new aluminosilicate phases. Such position of the band may suggest the formation of $\mathrm{N}-\mathrm{A}-\mathrm{S}-\mathrm{H}$ type gel, whose typical position in the IR spectrum is at $1,010 \mathrm{~cm}^{-1}$ [5]. The bands at about 1,420 and $875 \mathrm{~cm}^{-1}$ confirm the presence of carbonates. One new band at $619 \mathrm{~cm}^{-1}$ is also visible.

Action of $\mathrm{Na}_{2} \mathrm{SO}_{4}$ admixture

Activating action of $\mathrm{Na}_{2} \mathrm{SO}_{4}$, similarly to $\mathrm{NaOH}$, also is greatly reduced to increase the alkalinity of solution and 
improvement of solubility of fly ash grains as well. Many authors agree to the fact that in a medium containing calcium hydroxide, $\mathrm{Na}_{2} \mathrm{SO}_{4}$ reacts first with $\mathrm{Ca}(\mathrm{OH})_{2}$, and $\mathrm{NaOH}$ and gypsum are formed in this reaction $[9,15,22-24]$. Due to the significant contribution of aluminum compounds in the ashes, addition of gypsum promotes increase in degree of fly ashes reaction, because it favors the reduction of aluminate ions in the solution as the result of crystallization of ettringite. Thus, the influence of $\mathrm{Na}_{2} \mathrm{SO}_{4}$ consists of acceleration of early pozzolanic reaction and formation of more ettringite [15, 24]. C-S-H phase which is formed shows lower $\mathrm{C} / \mathrm{S}$ ratio than in Portland cement paste. Ettringite gradually converts to monosulfate; however, in case of fly ashes rich in aluminate compounds, it may exist for a long time. Carboaluminates arise always [13].

In the analyzed cases, it is evident that after adding of $\mathrm{Na}_{2} \mathrm{SO}_{4}$ sulfate ions are available for reaction in greater concentration compared to situation when fly ash alone is used. They react with aluminate and calcium ions to form hydrated sulfoaluminates. Probably, similarly as in case of hydration of Portland cement, ettringite arises first and then transforms to monosulfate. Such course of reaction in the case of paste of PK fly ash and $\mathrm{Ca}(\mathrm{OH})_{2}$ is confirmed by DTG curves (Fig. 4d1). Simultaneously, TG curves (Fig. 3d1) and resulting mass losses (Figs. 5, 6) demonstrate that in the analyzed samples, accelerating action takes place mainly through first 7 days of hydration. It confirms findings described in [15], where it was concluded that the activation effect of $\mathrm{Na}_{2} \mathrm{SO}_{4}$ happened mainly before 3 to 7 days. Introduction of $\mathrm{Na}_{2} \mathrm{SO}_{4}$ into the system of $\mathrm{PK}+\mathrm{Ca}(\mathrm{OH})_{2}$ results in visible differences in the shape of IR spectra (Fig. 8d1) at $1,200-900 \mathrm{~cm}^{-1}$, which is an evidence of a different mechanism of reaction and formation of additional sulfate phases (probably ettringite). A sharp band at about $1,105 \mathrm{~cm}^{-1}$ as well as effect at about $1,190 \mathrm{~cm}^{-1}$ appears. Formation of products of new hydrated aluminate and silicate phases are confirmed by the appearance of bands at 1,040 and $960 \mathrm{~cm}^{-1}$, wherein the first of these bands disappears over time and the second gains intense. At the same time, the intensity of the $\mathrm{OH}$ band vibration in $\mathrm{Ca}(\mathrm{OH})_{2}$ clearly decreases with time of hydration. Activating action of $\mathrm{Na}_{2} \mathrm{SO}_{4}$ with respect to mixtures containing large amount of fly ash was also confirmed by other authors [9, 24, 25].

The action of $\mathrm{Na}_{2} \mathrm{SO}_{4}$ is slightly different in case of $\mathrm{PB}$ paste. The acceleration effect occurring mainly during the first 3 days of hydration can be seen, and it discloses by greater amount of bound water (Figs. 3d2,7). The shape of DTG (Fig. 4d2) curves up to $100{ }^{\circ} \mathrm{C}$ is very similar to that obtained for a reference sample; however, there is a lack of clear effect of dehydration of aluminate phases at about $120{ }^{\circ} \mathrm{C}$ which is visible for all other samples containing
PB. It may suggest that at the adopted experimental conditions, aluminate phases prefer to create ettringite with the delivered $\mathrm{SO}_{4}^{2-}$ ions. The shape of IR spectra (Fig. 8d2) is also very similar to the results registered for reference. It may indicate that $\mathrm{Na}_{2} \mathrm{SO}_{4}$ admixture does not rise alkalinity of reaction environment to the extent allowing clear acceleration of dissolution of aluminosilicate units. Probably its action mainly consists in supplying sulfate ions to the reaction.

\section{Action of $\mathrm{Na}_{2} \mathrm{CO}_{3}$ admixture}

Clear influence of $\mathrm{Na}_{2} \mathrm{CO}_{3}$ on sample containing PK and $\mathrm{Ca}(\mathrm{OH})_{2}$, especially up to 7 th day of hydration, is visible. Till this time, the greatest amount of bound water and the lowest content of $\mathrm{Ca}(\mathrm{OH})_{2}$ in comparison to other activated samples are registered (Figs. 5, 6). These observations are also confirmed by IR spectra (Fig. 8c1), where clear reduction in the intensity of band of $\mathrm{OH}$ vibration in $\mathrm{Ca}(\mathrm{OH})_{2}$ is visible, and as early as on the 3rd day of hydration, the band of $\mathrm{C}-\mathrm{S}-\mathrm{H} / \mathrm{C}-\mathrm{A}-\mathrm{S}-\mathrm{H}$ phase at about $960 \mathrm{~cm}^{-1}$ appears. Within the band characteristic for carbonates, additional shoulder occurs at about $1,368 \mathrm{~cm}^{-1}$. It is possible that in the presence of $\mathrm{Na}_{2} \mathrm{CO}_{3}$, sodium calcium carbonate arises similarly as in case of activation of slagcement systems what was observed in $[22,26]$.

In the case of $\mathrm{PB}$, it can be seen that products formed of hydration in the presence of $\mathrm{Na}_{2} \mathrm{CO}_{3}$ are different in comparison with the reference. TG and DTG curves (Figs. 3c2, 4c2) indicate that when $\mathrm{Na}_{2} \mathrm{CO}_{3}$ is introduced, new hydrated products are formed. These new products are characterized by dehydration in broad temperature range, similarly as in the case of $\mathrm{NaOH}$ admixture and differently than for the reference sample. However, the amount of bound water is the lowest compared to other samples with PB (Fig. 7). The IR spectra (Fig. 8c2) are similar in shape to the spectra recorded for $\mathrm{PB}$ paste hydrating without additives. Deepening the band at about $996 \mathrm{~cm}^{-1}$ with hydration time proves that the reaction results in the formation of new phase of aluminosilicate.

\section{Conclusions}

1. Influence of chemical activators on pozzolanic and hydraulic properties of fly ashes strictly depends on the kind of fly ash and availability of $\mathrm{Ca}(\mathrm{OH})_{2}$.

2. In the case of fly ash PK and additionally introduced $\mathrm{Ca}(\mathrm{OH})_{2}$, the acceleration actions were observed for each activator used. Probably, it is an effect of faster dissolution of fly ash grains as an effect of high concentration of $\mathrm{OH}^{-}$in the reaction environments. However, mechanism of action of each activator and 
formation of chemical compounds depends on the kind of alkali compound used. Faster reduction of $\mathrm{Ca}(\mathrm{OH})_{2}$ was found for $\mathrm{Na}_{2} \mathrm{CO}_{3}$ admixture. In the case of $\mathrm{Na}_{2} \mathrm{SO}_{4}$, formation of sulfoaluminates was confirmed, while in the case of $\mathrm{NaOH}$, besides aluminosilicate gel $\mathrm{N}-\mathrm{A}-\mathrm{S}-\mathrm{H}, \mathrm{C}-\mathrm{S}-\mathrm{H}$ and hydrated aluminates are probably formed.

3. High-calcium PB fly ash exhibits some hydraulic activity which is developed during first days of hydration, earlier than pozzolanic activity of PK. The activation action of chemical admixtures used is also observed in the case of high-calcium PB fly ash but to a lower extent as compared to the samples of $\mathrm{PK}+\mathrm{Ca}(\mathrm{OH})_{2}$. The most active action is exhibited by $\mathrm{NaOH}$ solution. In other cases, the systems probably did not reach the appropriate alkalinity for easily dissolution of the ash particle, and entering them in reaction to form phases having binding properties.

4. It is possible that activation of PB may be improved by introducing to the reaction apart from alkaline admixtures also a small amount of $\mathrm{Ca}(\mathrm{OH})_{2}$, to facilitate the availability of $\mathrm{Ca}^{2+}$ ions. Such systems will be the subject of further research.

Open Access This article is distributed under the terms of the Creative Commons Attribution License which permits any use, distribution, and reproduction in any medium, provided the original author(s) and the source are credited.

\section{References}

1. Wongkeo W, Thongsanitgarn $\mathrm{P}$, Chindaprasirt $\mathrm{P}$, Chaipanich A. Thermogravimetry of ternary cement blends. Effect of different curing methods. J Therm Anal Calorim. 2013;113:1079-90.

2. McCarthy MJ, Dhir RK. Development of high volume fly ash cements for use in concrete construction. Fuel. 2005;84: 1423-32.

3. Arezoumandi M, Volz JS, Ortega CA, Myers JJ. Effect of total cementitious content on shear strength of high-volume fly ash concrete beams. Mater Des. 2013;46:301-9.

4. Huang C-H, Lin S-K, Chang C-S, Chen H-J. Mix proportions and mechanical properties of concrete containing very high-volume of Class F fly ash. Constr Build Mater. 2013;46:71-8.

5. Garcia-Lodeiro I, Fernandez-Jimenez A, Palomo A. Hydration kinetics in hybrid binders: early reaction stages. Cem Concr Compos. 2013;39:82-92.

6. Kulasuriya C, Vimonsatit V, Dias WPS, De Silva P. Design and development of alkali pozzolan cement (APC). Constr Build Mater. 2014;68:426-33.
7. Sajedi F, Razak HA. Comparison of different methods for activation of ordinary Portland cement-slag mortars. Constr Build Mater. 2011;25:30-8.

8. García-Lodeiro I, Fernández-Jiménez A, Palomo A. Variation in hybrid cements over time. Alkaline activation of fly ash-portland cement blends. Cem Concr Res. 2013;52:112-22.

9. Donatello S, Fernández-Jiménez A, Palomo A. Very high volume fly ash cements. Early age hydration study. Using $\mathrm{Na}_{2} \mathrm{SO}_{4}$ as an activator. J Am Ceram Soc. 2013;96:900-6.

10. Winnefeld F, Leemann A, Lucuk M, Svoboda P, Neuroth M. Assessment of phase formation in alkali activated low and high calcium fly ashes in building materials. Constr Build Mater. 2010;24:1086-93.

11. Criado M, Fernández Jiménez A, Palomo A. Effect of sodium sulfate on the alkali activation of fly ash. Cem Concr Compos. 2010;32:589-94.

12. Komnitsas K, Zaharaki D. Geopolymerisation: a review and prospects for the minerals industry. Miner Eng. 2007;20:1261-77.

13. Kurdowski W. Chemia cementu i betonu. Kraków: Stowarzyszenie Producentów Cementu; 2010 (in Polish).

14. Taylor HFW. Cement chemistry. 2nd ed. London: Thomas Telford; 1997.

15. Qian J, Caijun S, Zhi W. Activation of blended cements containing fly ash. Cem Concr Res. 2001;31:1121-7.

16. Pacewska B, Blonkowski G, Wilińska I. Studies on the pozzolanic and hydraulic properties of fly ashes in model systems. J Therm Anal Calorim. 2008;94:469-76.

17. Pacewska B, Blonkowski G, Wilińska I. Investigations of the influence of different fly ashes on cement hydration. J Therm Anal Calorim. 2006;86:179-86.

18. Pacewska B, Wilińska I, Blonkowski G. Investigations of cement early hydration in the presence of chemically activated fly ash. Use of calorimetry and infrared absorption methods. J Therm Anal Calorim. 2008;93:769-76.

19. Pacewska B, Wilińska I. Hydration of cement composites containing large amount of waste materials. Procedia Eng. 2013;57:53-62.

20. Wilińska I, Pacewska B. Calorimetric and thermal analysis studies on the influence of waste aluminosilicate catalyst on the hydration of fly ash-cement paste. Therm Anal Calorim. 2014;116:689-97.

21. Mozagwa W, Król M, Dyczek J, Deja J. Investigation of the coal fly ashes using IR spectroscopy. Spectrochim Acta Part A. 2014;132:889-94.

22. Radwan MM, Farag LM, Abo-El-Enein SA, Abd El-Hamid HK. Alkali activation of blended cements containing oil shale ash. Constr Build Mater. 2013;40:367-77.

23. Abdullah A, Jaafar MS, Taufiq-yap YH, Alhozaimy A, Al-Negheimish A, Noorzaei J. The effect of various chemical activators on pozzolanic reactivity: a review. Sci Res Essays. 2012;7:719-29.

24. Shi C, Day RL. Pozzolanic reaction in the presence of chemical activators Part II. Reaction products and mechanism. Cem Concr Res. 2000;30:607-13.

25. Shi C, Day RL. Pozzolanic reaction in the presence of chemical activators Part I. Reaction kinetics. Cem Concr Res. 2000;30:51-8.

26. Duran Atiş C, Bilim C, Çelik Ö, Karahan O. Influence of activator on the strength and drying shrinkage of alkali-activated slag mortar. Constr Build Mater. 2009;23:548-55. 